\title{
Divine Revelation in Yoruba Traditional Religion and In Christianity
}

\author{
Pius Oyeniran Abioje \\ Ph. D, Department of Religions, University of Ilorin, P. M. B. 1515, Ilorin, Nigeria.
}

\begin{abstract}
This paper discusses divine revelation in its various forms. The occasional conflict between some Christians and adherents of African Traditional Religion (ATR) in Yorubaland, Nigeria, was the motivation. Some large Christian population sometimes tried to prevent the adherents of Yoruba traditional religion from celebrating some of their festivals. One had attributed the conflicts to Christian absolutism and triumphalism. The impression seemed to be rife that ATR was not a revealed religion or that it did not enjoy divine revelation as applied to Christianity. It was discovered that in the view of many scholars, God is impartial, and no culture or religion has a monopoly of divine revelation. The Yoruba example also revealed that although the people did not know such biblical personalities as Abraham, Moses, David, and Jesus, they have corresponding names in their history. In place of the Bible, many scholars refer to the obviously resourceful Africa's "Oral Traditions", and even Africa's "oral literature". Christians in Yorubaland, and indeed all human beings, are, therefore, enjoined to cultivate humility, mutual respect, and brotherly sharing of knowledge and experience, since God is said to be impartial, and He alone is omniscient.
\end{abstract}

\section{Introduction}

The general belief of Christians is that Jesus Christ was God in human flesh (incarnation), and so $\mathrm{He}$ represented the fullness of God's revelation. Christians of that school of faith, who appear to be in the majority, find support especially in the Gospel according to John, where it is written that: "No one has gone up to heaven, except the one who came down from heaven, the son of Man who is in heaven" (Jn. 3:13), and: "To have seen me is to have seen the Father" (Jn. 14:9). Consequently, many Christians seem to see themselves as a privileged group who are superior to non-Christians. That assumption often ensues in a sense of arrogance that tends to make many Christians in Yorubaland denigrate the Yoruba religious traditionalists, and that sometimes results into violent conflict.

This study on the concept of divine revelation in Christianity and in African Traditional Religion (ATR) (with specific reference to Yoruba traditional religion) aims at establishing why Christians should not allow themselves to be consumed by superiority complex, but clothe themselves in humility, which can allow for mutual respect and harmony in a religiously pluralistic and culturally diverse society, such as Yorubaland, Nigeria. John the Baptist is quoted as warning the Jews not to pride themselves in being Abraham's children, but in being faithful to God as Abraham was, and in producing fruits of good deeds (Luke 3:8-9). Similarly, Haught (1996:885) notes that "a strong temptation to triumphalism can indeed accompany a naive doctrine of special revelation." One can add that religious triumphalism very often begets arrogance and conflict, with particular reference to a religiously pluralistic society. Tarnas (1991:318) notes that:

The Christian injunction to love and serve all humanity and high valuation of the individual human soul now stood in sharp counterpoint to Christianity's long history of bigotry and violent intolerance - its forcible conversion of other peoples, its ruthless suppression of other cultural perspectives, its persecutions of heretics, its crusades against Moslems, its oppression of Jews... its association with slavery and colonialist exploitation, its pervasive spirit of prejudice and religious arrogance maintained against all those outside the fold (Tarnas, 1991: 318).

That does not mean, of course, that Christians are always wrong and other peoples are always right. But issues can be raised for critical discourse, as one intends to do in this essay, toward religious peace in Yorubaland. Occasional clashes between Christians and adherents of Yoruba traditional religion in some Yoruba communities, such as Iseyin and Shagamu, formed the background of this study. The focus is Christians who tend to view their faith as the only repository of divine revelation. One has attributed the clashes to Christian absolutism and triumphalism.

\section{The Conceptual Framework}

This is an exercise in the study of divine revelation. It posits that an objective perception of divine revelation as a diverse phenomenon could help Christians to shed a sense of superiority complex which results in denigration and derogation of the faiths of other religionists. The study is comparative, as it compares divine revelation in Christian and Yoruba perspectives. It is also expository in the sense that it presents some scholars 
who have discussed God as a universal concept and Being who reveals Himself to the entire human race in one form or another, past, present, and continuous. Hebblelethwaite (1980:8) warns that:

Christians must cease to think of their faith as bearing witness to God's final and absolute selfrevelation to man. Rather they must learn to recognize their experience of God in Christ to be but one of many different saving encounters with the divine which have been given to different historical and cultural segment of mankind.

That consciousness seems indispensable to mutual and reciprocal respect, without which socio-political collaboration may be elusive in a religiously pluralistic society, such as Yorubaland. What is more, the whole idea of religious, racial, and cultural superiority has been dropped in many enlightened societies. Balogun (2012:7) asserts, for instance, that he is "not interested in extolling one religion above another", neither does he "consider one religion per se better than another." He believes rather that "religions are either acceptable or rejectable (sic) according to how their adherents practice them". Besides, he expresses what can be said to be the contemporary standpoint that:

Man is free to follow whichever religion in which he finds solace and tranquility. The final arbiter in the matter of faith and religious practice is God; and I believe that He has not put the judgment of a person's conviction in another person's hand.

That is the sum of contemporary civilization, which fully recognizes freedom of religion. Frankl (2000:149) is also of the view that "If religion is to survive it will have to become profoundly personalized religion which allows any human being to speak a language of his or her own when addressing himself or herself to the ultimate being." One would reconstruct that statement to read that if religion is to survive in Yorubaland and be devoid of violent crisis, it must be allowed freedom of practice. That is imperative if only because, as Troeltsch (1980:31) notes, "In our earthly experience Divine Life is not one, but many", while "to apprehend the one in the many constitute the special character of love." Of course, where there is no love, misunderstanding, hatred, and conflict ensue. But the basic concern in this study is the extent to which a realization of the fact that divine revelation takes diverse forms can help Christians to be more accommodating of other religionists in Yorubaland and elsewhere possibly.

Etymologically, the word "revelation" derives from the Latin revelare (to remove the veil), and the Greek translation is apocalypsis. In history of religions, two forms of divine revelation are recognized, namely, natural or general revelation, and special or historical revelation. The former is said to be accessible to human beings through the natural order, which includes creation, human experience, and the inner voice of conscience. Dulles (1992:94) notes that it is on the basis of natural revelation that Saint Paul could assert, as he has done, that "the Law of God is inscribed upon the human heart", so that those who have not got the code of the Law from God can accomplish by nature what the Law requires (Rm. 2:4). Thus, it is generally believed that God's revelation is open to all human beings, including of course the Yoruba of western Nigeria.

On the other hand, special or historical revelation refers to God's self-disclosure to individuals or groups through events within history. With particular reference to the Judaeo-Christian tradition, Scanlon (1994:747) observes that special revelation means: "God's self-disclosure in the history of Israel and in the life, death, and resurrection of Jesus of Nazareth". As Scanlon further notes, "the normative testimony to this divine revelation is the Bible." Some other Christians may add the catechetical book(s) of their church or churches, as the case may be.

One would think that God would appear irresponsible if He does not reveal Himself and His will to whoever is made by Him. As a corollary, human beings can be responsible for their deeds only to the extent to which they know the will of God. It is rightly said that there can be no sin, where there is no law. The question then arises: Can there be a "special revelation" which is indispensable for human salvation, but is unknown to the majority of human beings? The answer to that and similar questions are addressed, towards a clear understanding of the nature of divine revelation and mutual respect among human beings and their various traditions, with particular reference to Yorubaland.

\section{Divine Revelation in Christianity}

The universal recognition of God does not seem to be in doubt. Weil (2007:15) notes that "It is impossible to prove that at the dawn of history man had no religion and later acquired one; rather the very opposite is true, for from earliest recorded time we have evidence from man's religious practices and beliefs that he had some consciousness of God." That would be because, according to Weil (p.12), "Man, although now a fallen creature, has not completely lost the image of God in which he was made; some knowledge of God remains in him." With specific reference to how God reveals Himself to human beings, Weil (p.18) holds with theologians, such as Dulles (1992:94), Scanlon (1994:747), and Pinnock (1998:585), that God has given human beings "two books to read and to study: the book of nature and the book of God, the Bible." One would of course expect a Muslim to mention the Qur'an rather than the Bible, while a Yoruba might mention "Oral Traditions" (Idowu, 1996:5). Weil (same page) explains the book of nature thus: 
It is the world and the universe in which we live. There are no words in this book, yet all the things we see in it have a story to tell. The sun, moon and stars, the birds, animals and insects, the mountains, fields and rivers, the trees, flowers and fruit and finally, Man himself with all his amazing powers proclaim that there is a wonderful Person we call God who made all these things long ago.

That is confirmed by Karl Rahner, who is quoted by Dych (1994:715) as teaching that "God's grace and revelation have been present at all times and places creating the possibility of supernatural faith for all peoples." On the other hand, some other Christian theologians, such as Karl Barth, hold that genuine revelation is impossible outside of Jesus Christ (Pinnock 1998:585); Gollwitzer (1994:49-50) likewise quotes Karl Barth as teaching that "the linking of Christian thought about God with this supposed general knowledge is a fateful error, because important characteristics are imparted by what man thinks he knows of himself", while "Revelation seeks to rescue man from his own imaginings concerning the divine." That of course was similar to the Roman Catholic position before the Second Vatican Council (1962-1965), when the Church taught that Extra ecclesia nulla salus (there is no salvation outside the Church). As Dych (1994:714-715) notes, Karl Rahner's influence at the Council positively changed the Church's perspective on the reality and validity of general revelation.

What brought about the positive change of perception and attitude to the concept of general divine revelation, apparently, was considerable exposure to non-European cultures, in which some Christian thinkers encountered appreciable and impressive philosophical and theological insights and practices. Gollwitzer (1994:13) notes that "As knowledge of other cultures increased, and particularly of the great religions of Asia, the argument that Christianity stands at the top of a ladder of religious development had necessarily to give ground to a relativism which could recognise it as the supreme expression of religion only for our European civilisation". Similarly, Needleman (1980:70) relates what one Father Vincent said to him about his missionary experience in Africa:

He began by telling me that his own youthful fantasies about Africa had nothing to do with 'saving the heathen,' although even he was surprised at how little 'converting' went on. As a matter of fact, he had some interesting things to say about the whole missionary enterprise, how it needed to be re-interpreted in terms of human fellowship, rather than in the clichés about leading whole tribes or cultures into a new religion. 'I learned from these people far more than I ever taught them.'

The whole episode seems interesting. Note that when one takes a cursory look at many countries in Africa, with particular reference to many parts of Nigeria, it can be argued that not "little" but much "converting" had taken place, whereas Father Vincent was right in the sense that ATR remains highly resilient. Gbenda (2001:11) quotes two indigenous African missionaries (Utov and Okoro) as complaining that too many African Christians are "secretly attached to the traditional religious practices". Writing much earlier, Adiele (1984:191) affirmed that "It is impossible for the rich African culture and religion to be completely wiped-out even by modern changes." All of that shows the extent to which Africans appreciate their religion and culture, and it confirms the opinion of "Father Vincent" (above) who is a Western missionary, and the validity of universal divine revelation.

Nevertheless, there are still many Christian theologians who view the divine revelation contained in the Bible as unique, superior, and indispensable to human salvation. For many of such theologians, the Bible contains the direct and normative Word of God to which no other source is comparable. Along with Karl Barth who was quoted earlier, although Weil (2007:18) believes unequivocally in "the book of nature", he also notes categorically on page twelve that "Christians believe that God has revealed himself to man and that these revelations have been written down and collected together in a book that we call the Bible - the only true source of religion." He repeats the Christian conviction again on page fifteen thus: "The Bible gives the only reliable account of the origin of religion by informing us of the existence of God, infinite and yet personal, the only object worthy of worship, who revealed himself to man and created him in his own image". That, of course, explains revelation from a Christian perspective. Nevertheless, in the words of Dulles (1992:103):

A comprehensive doctrine of revelation cannot limit itself to God's self-disclosure in biblical times; it must deal with God's active presence to the Church and the world today, without which the good news of the gospel, which is admittedly normative, might easily be dismissed as a piece of inconsequential historical information.

In that wise, it is said that divine revelation could not have ended with the death of the last Apostle. It seems unimaginable that God would, at any time, cease revealing Himself to those He has created in His own image, and more so to those He is said to have specially chosen for Himself through the life, death, and resurrection of the Lord Jesus. Scanlon (1994:747) explains that revelation was conceived as the unveiling of certain truths to be believed by faithful Christians in the Roman Catholic tradition. As he further notes:

This 'truths-belief' paradigm led people to conceive of revelation as 'information from the Beyond' to be accepted on the authority of God revealing through the mediation of the ecclesiastical magisterium .... This 
idea that revelation, so understood, ended with the last apostle and was stored in a 'deposit of faith' rendered revelation something static, past, and closed.

One would think that religious persons would fossilize if God were to stop illuminating them at any point in history. For instance, the Jews were said to be miserable when God would not send them prophets (Psalm 74 :9). The human agents of divine revelation in the Old Testament were, basically, the prophets. The Lord Jesus Himself was said to be a prophet, as well as being the Messiah. But, in the New Testament, God is said to have guided His people through the Apostles. Even Saint Paul, who was not a disciple of Jesus Christ in His earthly ministry, called himself an apostle, rather than a prophet as such (cfr., for instance, Rm. 1:1). The words "prophet" and "apostle" are, however, not to be counter-posed, since the apostles were known to have performed prophetic roles.

Equally worthy of note is that many theologians today do not believe that there are impeccable agents of God, both in the Bible and outside of it. In that respect, Riffel (1978:39) notes, for instance, that all who heard from God needed "correction, reproof, or confirmation, just as we do." As he further notes, the fact that the Old Testament contains no pretext that the prophets were more than human beings is testified to by such stories as the inability of Samuel to recognize the voice of God (1Sm. 3:1-14). And, in his epistle, Saint James notes that "Elijah was a human being like ourselves" (James 5:17). Likewise, Saint Peter was rebuked several times by the Lord Jesus (cf. for instance, Luke 22:31-34 \& John 13:36-38). Beyond that, he was said to have denied knowing Jesus Christ three times, at the critical moment of the latter's travail. It is interesting to note that the story is carried by all the Gospel accounts (Mt. 26:69-70; Mark 14:66-68; Luke 22: 57-59; and John 18:17-18). On one occasion, Peter was also seriously rebuked by Paul (cfr. Gal. 2:14). It should not be forgotten that Peter is only being used as a case study to emphasize that biblical agents of God were human beings in every sense of the word. Another typical example is Paul who spoke about the sinful nature of human beings as it applied to himself personally (Rms. 7:18 - 20).

The hagiographers who were the authors of the books in the Bible are believed to be inspired by God who imbued them with inerrancy. In his second letter to Timothy, Paul maintains that: "All scripture is inspired by God and can profitably be used for teaching, for refuting error, for guiding people's lives and teaching them to be holy" (2Tim. 3:16). It would seem, nevertheless, that many biblical scholars today are of the opinion that while the scripture contains the fundamental truth that can lead one to salvation, some elements of imperfection cannot be ruled-out, based on human limitation. As Murphy (1978:69) explains, for instance, "the human author is not shunted into the background", and so, the Scripture constitutes "the product of God and of man."

Understandably, since no human being is believed to be perfect, and the hagiographers enjoyed their autonomy in the choice of method and materials, the Scripture cannot be said to be the simple word of God. A typical example of the human element is when Saint Paul forbids women from speaking in the assembly of God's people, and that they should not give any teaching to their husbands (cf. 1Cor. 14:34-35, 1Tim. 2:12 15). That instruction from Paul might have been culturally expedient and wise in his own milieu, but that is not the case in most contemporary situations, in which there are female ecclesiastical overseers or bishops, and pastors of various categories, who lead liturgical services, and render brilliant homilies, offer exhortations, instructions and injunctions. Holman Illustrated Bible Dictionary (2003:825) notes that "normally God used His chosen writers' personalities, theological meditations, and literary styles." In other words, God never wrote directly by Himself.

On another note, there has been some attempt to review the traditional understanding that God's most definitive and final revelation has taken place in Jesus Christ, through the Incarnation. In the words of Scanlon (1984:747):

Thanks to the biblical scholarship of the twentieth century, we now have significant knowledge about Jesus of Nazareth. This knowledge informs contemporary attempts to construct a theocentric Christology wherein the fundamental issue is not the divinity of Christ but the kind of God disclosed by Jesus in his words, deeds, and destiny.

One would think that this new perspective of the reality of Jesus makes a continual search for God necessary in and outside of Christianity, in and outside of the Bible, to include human encounters, and certain historical events that are experienced by individuals, social groups, communities and societies that believe in God as the supreme Lord of history. For instance, it is possible to experience God's love in one's neighbour. A person can also experience God's almightiness in the fall of a supposedly powerful man or woman. Some illness may be the route to some discovery about God for some people. Failures and successes and awareness of happenings around can serve as private modes of divine revelation for those who are disposed to knowledge of God. Some people also claim to have divine revelations through dreams and visions. All these may be termed subjective, without suggesting that they are impossible or false in every case. 


\section{Divine Revelation in African Traditional Religion}

A spiritual religion, such as the African Traditional Religion (ATR), may not possibly exist without being rooted in God. As Awolalu and Dopamu (2005:1) note, "religion can only come as a result of the activities of two agents - God who reveals Himself to man, and man who apprehends and responds to God's revelation." The general and apparently incontrovertible belief is that Africans worship the same God that is known universally as the Creator of heaven and earth. Or, to put it in the words of Balogun (2012:4) that "the recognition of God as an object of worship, love and obedience which ultimately leads to practical piety and morality, is common to all [the] three religions practiced in Nigeria, i.e. African Traditional Religion, Islam and Christianity." In a similar vein, Awolalu (1981:3) notes in respect of Yoruba indigenous religion that: "The indigenous Yoruba believe in the existence of a self-existent being who is believed to be responsible for the creation and maintenance of heaven and earth, of men and women, and who also has brought into being divinities and spirits who are believed to be his functionaries in the theocratic world as well as intermediaries between mankind and the self-existent Being." What is more, ATR also has two books of revelation: the book of nature, and the book of Oral Tradition (the unwritten word of God in the word of human beings that is passed from one generation to another, orally). Writing specifically about the Yoruba, Idowu (1996:5) notes that:

As there are no written records of the ancient past of the people, all that has been preserved of their myths, philosophy, liturgies, songs and sayings, has come down to us by word of mouth from generation to generation. And all this together we shall call 'Oral Traditions'. These oral traditions are our only means of knowing anything at all of their theogony and cosmogony and what they think and believe about the relationship between heaven and earth.

One can note in Idowu's book that he uses "oral traditions" as Christians would use the Bible, and Muslims the Qur'an. Indeed, the book is basically on the Yoruba's faith in God, as found in the people's "myths, philosophy, liturgies, songs and sayings", which are among the sources of African theology, which Healey and Sybertz (1996:34) describe as "oral literature", on the basis of which they term African theology as "narrative". On page twenty-eight, Healey and Sybertz quote one Anne Nasimiyu-Wasike as stating that "The oral literature of the African people is their unwritten Bible", and "religious wisdom is found in African idioms, wise sayings, legends, myths, stories, proverbs and oral history". According to Healey and Sybertz, the word "proverb" is inclusive of such things as maxims, adages, pithy sayings, and aphorisms, which encode "the philosophical outlook, religious concepts and worldview of African society in a digestible form". Although proverb is a universal concept, Africans are very famous for their proverbs, most probably because it makes up for their late literacy. What is more, there is evidence of divine inspiration, and an appreciable degree of inerrancy in the proverbs, maxims, adages, etc.

The Yoruba, like the other African peoples, have practically innumerable proverbs. On a particular website, "62 Famous Yoruba Proverbs" are listed (Internet 2012). Number 28 on the list states that "No one can uproot the tree which God has planted"; while number 54 teaches that "When you stand with the blessings of your mother and God, it matters not who stands against you", both of which indicates God's supremacy and invincibility. Another famous but unlisted Yoruba proverb holds that: God drives away flies for a tail-less cow (i.e. God helps the helpless; it thus expresses God's providential quality); and another is that: A person who hides under a mortar to commit evil, if not seen by an earthly king, is seen by the heavenly One (which expresses God's omniscience, omnipresent, and omnipotence).

African theology of revelation is summed-up by Kayode (1984:2) thus:

Revelation is an act of God and to the understanding of African peoples, divine message can be obtained through the situation of things in their environment. Man has consciousness or self-awareness of the Divine Order. Without any hesitation, the African affirms that God has put this awareness in man and for this reason his traditional religion is found everywhere. His experience attracts him into religion. The works of Nature - rivers, hills, rocks, forests - instill the awareness in man that there is a superior Force greater than himself. The experience derived from Divine Providence - abundance of food for human beings and animals, procreation, growth and development of plants and crops - instills in man the awareness of a superior Force in the universe. Indeed, the experience of adversity in the form of epidemics, poor harvest, infant mortality, drought, etc. also calls for religious awareness. At such times, people then turn round and blame their suffering on some external force. There may be need to appease the gods, the divinities or the ancestors. When things go well and life is pleasant, Africans give praise and thanks to God from whom all blessings are supposed to flow.

All of that seems to be well-said. One would like to dwell a little bit on the subject of myth as a medium of divine revelation, generally speaking. It has been observed by many biblical theologians that at least the first eleven chapters of the book of Genesis contain religious lore and legends that are classified as myths.

Thus, the use of myths is not limited to African tradition. The word "myth" translates the Greek mythos, which means a fable, otherwise called a tale of fiction. Brown (1990:31-32) notes that the author(s) of Genesis must have learnt the stories from popular "legendary imaginings", and used them to convey the lesson that "God is sovereign of all and creator of the universe." One can add that the first eleven chapters of Genesis 
are not the only portion of the Bible that contains mythological stories. The Book of Job, for instance, has been used to answer several life puzzles, but there are indications within the text that it is a composed work. A critical study of the opening chapter of the book is sufficient to realize that the story is not historical but fictional. A commentator in the study edition of The Jerusalem Bible (1985:753) notes that: "The Book of Job is the literary masterpiece of the wisdom movement." In the African context, Oso (1979:22) notes that African myths represent "the mental effort of African ancestors to interpret the various cosmological and biological phenomena that they experienced." Thus, in contemporary understanding of myths and legends, they are taken as constituting a sacred tradition or primordial revelation. In that sense, every myth or legend expectedly has some sacred lesson to teach, beyond the material detail. Tikpor (1983:369) notes that: "If theology may be defined as a supernatural science which treats of God and of creatures in their relationship to God, then the myth is indeed a depositum of natural theology." It is worth noting that many of the Yoruba myths are now found in books by scholars, such as Idowu (1996:17-27 \& 54-107), Oso (1979:25), as well as Awolalu and Dopamu (2005:54-72). Basically, the myths portray God as the Supreme Being, who is the Creator, and the Alpha and Omega of the universe.

In addition to the book of nature and oral traditions, the Yoruba, like the other African peoples and humanity, generally speaking, believe in private divine revelation through human mind, human experiences, dreams, and visions. Haught (1996:886-887) notes how the Second Vatican Council, in its "Dogmatic Constitution on Divine Revelation" has challenged "us to think of revelation not as a collection of timeless formulas, but as an always enlivening embodiment of God's word that can illuminate and transform each new situation in a special way." That of course expresses the dynamic nature of divine revelation. Similarly, Haught (p. 884) has this to say on divine self-communication:

As Karl Rahner has often insisted, revelation is fundamentally the communication of the mystery of God to the world. This divine self-communication influences the world at every phase of its coming-to-be, and not just within the confines of the biblical world alone. Revelation is the ongoing outpouring of God's creative, formative love into the entire world.

Comparatively, revelation cannot be limited in African perspectives to ancient divine "oral traditions" of inherited knowledge about God. Indeed, the oral traditions, as evident in the proverbial examples (above) indicate that God in African worldview is not the same as the withdrawn God of the Deists, but is eternally ruling the world.

Along with the various forms of divine revelation already discussed, one should touch on the issue of prophecy in ATR. If a prophet signifies a person who gives a message in God's name, then, it is difficult to imagine that traditional Africans would have no prophets. In the words of Preus (2001:86), "Prophecy interprets the spiritual meaning of present events, condemns wickedness, both open and hidden, and makes warnings or promises about what God is going to do within history." One's observation is that such men and women exist, particularly in African priests and priestesses, in talented diviners, and in any other person(s) that God may choose to deliver His message and champion His cause among the people. Idowu (1996:5) already noted that traditional Africans "believe priests and diviners to be the interpreters of the will of the Deity". Parrinder (1975:122) also notes that many African diviners are men and women with "wide experience, keen perceptiveness, and deep intuition". He notes further that:

There is undoubtedly some degree of telepathy and extra-sensory perception at work at times. The great popularity of the diviner shows that he has a leading function to perform in society, and this he does as mediator and guide in many quarrel, trouble and sickness.

All that Parrinder has mentioned implies a gift(s) of God to certain individuals for the benefit of the people. Many Africans believe that there are certain persons with insight and divinatory talents, and so, they patronize such individuals. One's experience in Yorubaland is that many Christians and Muslims are also known to visit them covertly or overtly, directly or indirectly by proxy.

\section{Revelation vis-à-vis God's Impartiality to All Peoples}

For Muslims, the Qur'an is not only a holy book. It is unique and extraordinary because Allah is its author. It gives a recapitulation of all preceding revelation. It is entirely God's Word (Molla, 1997:16)

Generally speaking, that is the Muslim position, as noted by Molla (1997:16). Indeed, many Muslims hold Islam to be the most up-to-date religion, and Muslims to be the latest People of God, even though they appreciate Judaisers and Christians. Like its Judaic and Christian counterparts, that form of self-estimation is regarded in many academic circles as both subjective and absolutist in disposition. Contrary adjectives are "objective" and "liberal" or un-dogmatic dispositions. At a point in history, the Jews thought they alone belonged to God, and that they alone knew God. They appeared oblivious that God revealed Himself to other peoples. That sentiment is clearly indicated in the story of the contest between Prophet Elijah and the priests of Baal (1Kgs. 18:22-20). That conviction also informed such phrases as "God of Israel" (2Kgs. 19:15) and "the Holy one of Israel" (2Kgs. 19:22; Ps. 71:22; Isa. 1:4; Jer. 51:5 and Ez. 39:7). Later in history, the belief that 
Jesus Christ was the ultimate revelation of God (Jn. 14:9) culminated in the exclusive claim that Christians are the new People of God, and that made the Jews to be regarded as the old People of God. Jesus Christ is reported as congratulating the Apostles, saying: "I tell you solemnly, many Prophets and holy men longed to see what you see, and never saw it; to hear what you hear, and never heard it" (Mt. 13:17). That is a form of special revelation. Dulles (1992:101), writing on the subject of special and absolute claim on revelation, notes that: "the limitations imposed by the particularities of time and culture, has difficulty in admitting that there can be any absolute or unsurpassed disclosure within history." On a much more elaborate note, Haught (1996:885) observes that:

In order to obviate arrogance, many contemporary theologians emphasize that the primary meaning of revelation is God's gift of self to the world. Such a formula prohibits our restricting this gift to a specific Church community. Revelation in its fundamental meaning is universal. If we still continue to speak of a special historical revelation, we do not mean that it is special in the sense that the people to whom it is communicated are thereby superior to other human beings. Nor do we mean that they are any more valued by God.

The biblical basis for emphasizing that "God's gift of self to the world" is universal is found in such passages as Romans 1:20, where the author notes that: "Ever since God created the world, his everlasting power and deity - however invisible - have been there for the mind to see in the things he has made". Psalm 50:12 also quotes God as saying that "the world and all it holds is mine". By way of application, with specific reference to the Roman Catholic Church, Scanlon (1994:749) observes that:

With the new appreciation of world religions, the Roman Catholic Church has in principle extended the need for ecumenical conversation beyond the Christian pale. As Catholics, we are Christocentric, but we are not Christomonist. While we witness to Christ in our dialogue with people of other religions, we would expect to learn more about the God of Jesus who is Promise for all people.

That seems to represent the current position in the liberal Roman Catholic and Protestant camps. Taylor (1976: v), who was an official of the World Council of Churches, once observed that: "Our neighbours with primal views on life and ways of life have much to teach us" (just as Christians may have much to teach them, since only God is said to be omniscient). Human beings can always learn from one another, generally speaking, if there is humility and openness of mind. Jesus Himself is quoted as saying, on several occasions, about some Gentiles, that: "In truth I tell you, in no one in Israel have I found faith as great as this" (Matt. 8:10; Like 7:9).

The foregoing is a testimony to the fact of some amazement in the content of the philosophy, theology, and general epistemology of peoples, such as Africans, who lay no claim to special revelation as in Judaism, Christianity, and Islam.

The points highlighted by Scanlon and Taylor make it reasonable and fair to assume that like the biblical hagiographers, African sacred artists are both inspired and inerrant, as far as humanly possible, since God is also the Lord in their historical narratives, in their myths and other forms of fiction. Realising how God blessed a Gentile household, Peter could not help saying: "The truth I have now come to realise is that God does not have favourites, but that anybody of any nationality who fears God and does what is right is acceptable to him" (Acts 10:34). The statement expresses God's impartiality in respect of every people and individual human being created in the imago Dei.

One discovered that traditional Africans don't know such personalities as Abraham, Moses, David, and Jesus Christ, but along with the name of God, certain names are found in their oral and the emerging literary traditions. Among the Yoruba, for instance, the people of Ile-Ife are not likely to ever forget Lady Moremi who is said to have risked her life, and offered her only son, Oluorogbo, in sacrifice for the liberation of her people.

Likewise, the Ijesha Yoruba immortalize the name of Obokun, who played a role that was similar to that of Moremi, and the Egba Yoruba commemorate their ancient political liberator, Lishabi (Biobaku, 1991:811,32). For the Yoruba of Ijebu-Ode it is Obanta, while the Ibadan Yoruba celebrate the memory of Oluyole. Collectively speaking, Oduduwa corresponds in Yoruba context to Father Abraham in Judaeo-Christian history (Ajayi and Smith, 1971:1-2) . Many local martyrs, heroes and heroines are also known in traditional African societies and communities, in whose bibliographies God can be said to have revealed Himself in a special way. Jesus Christ is quoted as saying: And I tell you that many will come from east and west and sit down with Abraham and Isaac and Jacob at the feast in the kingdom of heaven; but the children of the kingdom will be thrown out into the darkness outside, where there will be weeping and grinding of teeth (Matt. 8:11-12).

The bottom line is that whether in Christianity, ATR or any other authentic religion and culture, it does not seem that God has left anybody or people without revealing Himself to them, one way or another, whether in the past or at the present time, and on continuous basis. The modes of revelation have also been found to be similar in many respects. God is said to have revealed Himself to human beings through the created order, oral and written traditions, some human mediums, historical experiences, conscience, creative and philosophical works of art, as well as in dreams and visions. Of course, each case requires discernment for authentication in its own context. 


\section{Conclusion}

This study sought to establish why Christians should not allow themselves to be consumed by superiority complex or a form of triumphalism that may injure human unity and solidarity, and create conflicts in a religiously pluralistic society, such as Yorubaland. Some quotations (above) indicate that many Christians have realized that in spite of the doctrine of the Incarnation, God, as a spiritual Being, remains largely mysterious and unmonopolisable. Nobody seems to possess the key to completely unravel God's invisibility, incomprehensibility, and intractability. That makes nonsense of any form of triumphalism, arrogance or pretentiousness in respect of divine revelation. Wisdom demands, therefore, that Christians in Yorubaland, and indeed all human beings, cultivate humility, mutual respect, and brotherly sharing of knowledge and experience.

\section{Works Cited}

[1] Adiele, S. N. 1984. "Religious C-Operation in Eastern Nigeria", in Sam Babs Mala and Z.I. Oseni (eds.), Religion, Peace, and Unity in Nigeria. Nigerian Association for the Study of Religions, pp.183-206.

[2] Ajayi, J.F. Ade. and Robert Smith. 1971. Yoruba Warfare in the $19^{\text {th }}$ Century. Ibadan University Press.

[3] Awolalu, J. Omosade. 1981. Yoruba Beliefs and Sacrificial Rites. Essex: Longman Group Ltd.

[4] Awolalu J. Omosade \& P. Adelumo Dopamu. 2005. West African Traditional Religion. Ibadan: Macmillan Nigeria Publishers Limited.

[5] Balogun, I.A.B. 2012. "Religious tolerance is a Prerequisite for Peace", in I.A.B. Balogun (ed.), Religious Understanding and CoOperation in Nigeria: Proceedings of A Seminar Organized by the Department of Religions, University of Ilorin, Ilorin, Nigeria. Ilorin: Department of Religions, University of Ilorin, pp. 1-9.

[6] Biobaku, Saburi O. 1991. Egba and their Neighbours. Ibadan: University Press Plc.

[7] Brown, Raymond E. 1990. Responses to 101 Questions on the Bible. New York: Paulist Press.

[8] Dulles, Avery. 1992. "Faith and Revelation”, in Francis Schussler Fiorenza and John P. Galvin (eds.), Systematic Theology: Roman Catholic Perspectives. Dublin 8: Gill and Macmilan Ltd., pp. 91-128.

[9] Dych, William. 1994. "Rahner, Karl (1904-1984)", in Michael Glazier and Monika K. Hellwig (eds.), The Modern Catholic Encyclopedia. Minnesota: The Liturgical Press, pp. 714-716.

[10] Frankl, Viktor E. 2000. Man's Search for Ultimate Meaning: A Psychological Exploration of the Religious Quest. New York: MJF Books Fine Communications.

[11] Gbenda, Joseph S. 2001. The Africanization of Christianity. Nsukka: Chuka Educational Publishers.

[12] Gollwitzer, Helmut. 1994. "Introduction”, to Karl Barth: Church Dogmatics: A Selection with Introduction by Helmut Gollwitzer. Edited by Michaelmas Pasadena. Kentucky: Westminster John Knox Press, pp. 1-28.

[13] Haught, John F. 1996. "Revelation", in Joseph A. Komonchak, Mary Collins, and Dermot A. Lane, The New Dictionary of Theology. Bangalore: Theological Publications in India.

[14] Healey, Joseph and Donald Sybertz. 1996. Towards an African Narrative Theology. Kenya: Paulines Publications Africa.

[15] Hebblethwaite, Brian. 1980. "Introduction", in John Hick and Brian Hebblethwaite (eds.), Selected Readings: Christianity and other Religions. Glasgow: Fount Paperbacks, pp. 7-9.

[16] Holman Illustrated Bible Dictionary. 2003. Edited by Chad Brand, Charles Draper, Archie England, Steve Bond, E. Ray Clendenen, Trent C. Butler (eds.), and "Reconstructions" by Bill Latta. Tennessee: Holman Reference.

[17] Idowu, E. Bolaji. 1996. Olodumare: God in Yoruba Belief. Ikeja: Longman Nigeria Plc.

[18] Internet. 2012. "62 Yoruba Proverbs". http://www.special-dictionary.com/proverbs/source/y/yoruba_proverb/7.htm

[19] Kayode, J.O. 1984. Understanding African Traditional Religion. Ile-Ife: University of Ife Press.

[20] Molla, Claude. 1997. Islam and Christianity: 150 Questions and Answers, translated from the French by Ronald

[21] Nelson. Ibadan: PROCMURA.

[22] Murphy, Richard T. A. 1978. Background to the Bible: An Introduction to Scripture Study. Michigan: Servant Books.

[23] Needleman, Jacob. 1980. Lost Christianity. New York: Doubleday \& Company, Inc.

[24] Oso, S. O. 1979. Lectures on West African Traditional Religion. Ado-Ekiti: Bamgboye \& Co. Press (Nig) Ltd.

[25] Parrimder. E. G. 1975. African Traditional Religion. London: Sheldon Press.

[26] Pinnock, C.H. 1998. "Revelation", in Sinclair B. Ferguson, David F. Wright, and J.I. Packer (eds.), New Dictionary of Theology. Illinois: Inter-Varsity Press, pp. 585-57.

[27] Preus, Jonathan. 2001. Reading the Bible through Christ: An Introduction to Exegesis and Interpretation. Bukuru: TCNN Publication, 2001

[28] Riffel, Herman H. 1978. Voice of God: The Significance of Dreams, Visions, Revelations. Illinois: Tyndale House

[29] Publishers, Inc.

[30] Scanlon, Michael J. 1994. "Revelation", in Michael Glazier and Monika K. Hellwig (eds.), The Modern Catholic Encyclopedia. Minnesota: The Liturgical Press.

[31] Tarnas, Richard. 1991. The Passion of the Western Mind: Understanding the Ideas that have Shaped Our World View. New York: Harmony Books.

[32] Taylor, John B. 1976. "Preface", to John B. Taylor (ed.), Primal World Views: Christian Dialogue with Traditional Thought Forms. Ibadan: DaySrar Press.

[33] The Jerusalem Bible. 1985. "Introduction to the Book of Job" (author un-identified inside the Bible). London: Darton, Longman \& Todd Ltd., pp. 753-756.

[34] Tikpor, Robert G. 1983. "Myths", in E. A. Ade Adegbola (ed.), Traditional Religion in West Africa. Ibadan: DayStar Press.

[35] Troeltsch, Ernst. 1980. "The Place of Christianity among the World Religions", in John Hick and Brian Hebblethwaite (eds.), Selected Readings: Christianity and other Religions. . Glasgow: Fount Paperbacks, pp. 11-31.

[36] Weil, Roger. 2007. Foundations of the Christian Faith. London: Grace Publications Trust. 